\title{
The Decision Making of Silariang
}

\author{
Ayu Ramdhani S \\ Department of Psychology \\ Hasanuddin University \\ Indonesia \\ ayuramdhani@gmail.com
}

\author{
Muhammad Tamar \\ Department of Psychology \\ Hasanuddin University \\ Indonesia
}

\author{
Sulasmi Sudirman \\ Department of Psychology \\ Hasanuddin University \\ Indonesia
}

\begin{abstract}
Women in Makassar tribe become a representation of sin'. In social relation with man, women are more demanded to guard their honor, family and community, including in terms of marriage. However, there are many of marriage do not correspond to the custom, called silariang. Women of Makassar tribe who should guard their honor, family and community still take a decision to do silariang. This study aims to elaborate the process of decision making of silariang in women of Makassar tribe. The participants of this study are 3 women of Makassar tribe. To analyze the data, the writer used qualitative method. The results of this study indicate that factors that lead women of Makassar tribe to do silariang are conflict between father and spouse, inability of spouse to fulfill amount of uang panai', unwed lock pregnancy, and also having emotional dependence with their spouse. Psychological reactions that arise from silariang are sadness and regret. External impact of silariang is the relationship between family declined. Silariang begins with main factor and reinforcing factor that make screening, editing, and selection phase produce a decision to silariang. In decision consolidation phase is found that it can reduce regret. This study finds that silariang becomes "new way" in attempting to defend love of women and men. Silariang considered has consequence and risk is lighter, so that it tends chosen as a decision.
\end{abstract} Tribe

Keywords-Decision making; silariang; women, Makassar

\section{INTRODUCTION}

Marriage becomes one of important tradition in Makassar tribe. Israpil argues that marriage is one of siri' manifestation in social life. Marriage is held according to strict traditional rule [1]. In its social relations with men, Makassar society makes women as a symbol of siri', by placing women as a representation of family dignity, as women determine family degree of dignity. However, there are women in Makassar who choose to marry a man in a way that discord with siri' tradition. These women choose to elope.

Decision making is influenced by social environment, especially what others think regarding certain decision [2]. In Makassar tribe, making aincluding whom to marry and how to hold a wedding is determined by customary provision. silariang or eloped is violating siri' tradition. However, there are women who decide to do it.

This present study aims to get a better understanding of why do women decide to elope. This study expected to contribute to indigenous psychology especially in eastern Indonesia. In addition, this study also will provide information to get a better comprehension to explain silariang in Makassar tribe. Moreover, this study is also serve as source of learning especially to Makassarese to positively re-interpret its cultural values in order to preserve local culture.

\section{LITERATURE REVIEW}

\section{A. Decision making}

Decision-making is cognitive processes to choose a preferred alternatives based on certain criteria and strategies. [3]. Ranyard, Crozier, Svenson [4] explains that decisionmaking is regarded as an interaction between decision makers, problems faced, and how the problem is placed in the social context. Decision-making is the process of determining decisions based on certain considerations, whether derived from the self or internal factors, as well as the environment or external factors.

\section{B. Aspects of decision making}

Kemdal \& Montgomery [4] argues that decision making is influenced by aspects of circumstances, preferences, emotions, actions, and beliefs. In aspect of circumstances, a decision is influenced by presence of external situation and influence of others. Preferences is an aspect which related with individual's desires, hopes, and goals. Aspect of emotions related with feelings, positive or negative reaction. Then, aspect of actions, such as an interaction or discussion with others, look for an information about alternative options, make a plan, and make a commitment. In aspect of beliefs, people know and believe about the decision and impact of the decision.

\section{Stages of decision making}

The decision-making stage is based on the differentiation and consolidation theory of decision making (Diff Con Theory). Svenson [4] argues that the basic assumption of this theory is that the objective of the decision is not only to choose the best option when a decision is made, but also to choose the option that will remain best after the decision is taken. The stages consist of: Recognition decision problem; differentiation, which consists of screening, editing, dan selection; and decision consolidation. 


\section{Silariang}

Silariang refers to elopement conducted by men and women based on their will. This form of marriage is violating the customary law [1]. There are several reason why men and women do elope, mostly, it is cause by opposing matchmaking, economic factors, differences in social status, and bad behavior of men to whom the women wants to marry. Because it is violating the customary law, there are some consequences of silariang, namely:

1. Because silariang violates customary law, it cause shame in men and women who elope as well as the family.

2. Silariang might cause death in the perpetrator for triggering a bloodbath between tumasiri 'and tumanyala'.

3. Women's family consider silariang as an affront, because it breaks the matchmaking ropes in the relative's. Thus, silarang will cause tension in family and relatives.

\section{METHOD}

\section{A. Participants}

There are three participants participated in this study. These participants were selected by purposive sampling. Sample were selected based on criteria: Makassarese women; conducted silariang in maximum 3 years ago.

This criteria of maximum 3 years after conducted silariang were set based on Svenson's differentiation and consolidation theory of decision making, which explain that decision making process last before and after decision is made. As such, 3 years of marriage is set as one of criteria of selecting participants.

\section{B. Procedures}

Data was obtained from in-depth interviews and documentation. In conducting in-depth interview, semi structured interviewed were performed. In addition, investigator also collecting data from on-site field recording and documentation of supporting documents such as images and letters.

\section{Data analysis}

A qualitative phenomenology research was conducted based on Stake stages of analysis [5]. Accordingly, in analysis qualitative data, epoche or bracketing technique is employed. This techniques attempt to reduce or delay judgment. Next, horizonalization, which is grouping each statement relevant to the topic. And lastly, clusters of meaning which refers to grouping statements into themes or units, deleting overlapping and repeated statements.

For validity, triangulation as proposed by Creswell was employed [5]. Triangulation was performed by involving proof-of-amplifier evidence from various sources. Investigators were reviewing and discussing the data obtained. Next step is member checking, which involves returning data, analysis of interpretation, and conclusions from participants. Lastly, rich and thick description, which makes the description rich and thick, detail about the results of research. In addition, investigators also use inter-coder agreements to check reliability of data analysis [6].

\section{RESULT}

\section{A. Participants profile}

There were 3 women participated in this study. These women conducted silariang in maximum three years ago. The profile of participants is described in Table I.

TABLE I.

\begin{tabular}{|c|c|c|c|c|}
\hline Initials & Age & Origin & Age of spouse & Age of marriage \\
\hline HY & 20 & Gowa & 23 & 1 year 9 months \\
\hline NA & 29 & Jeneponto & 33 & 3 year 2 months \\
\hline RM & 18 & Gowa & 19 & 2 months \\
\hline
\end{tabular}

\section{B. Factors influencing decision to do silariang.}

The result of this study shows that there are two factors influencing decision to do silariang. These factors are main factor and reinforcing factor. The main factors include external factors, which the most dominant factors determine decision to do silariang are: conflict between fiancée and parents, the inability of fiancée to meet the amount of uang panai' which is the certain amount given by the groom to the bride which is used to hold the wedding. Traditionally, the number of money represent the social status also the honor and dignity of the women [1]. Another factor influencing decision to do silariang is wedlock pregnancy. The dominant reinforcing factors are feelings which is perceived as love to fiancée. When women from Makassar tribe is faced with external factors to do silariang, and is supported by presence of internal factors, tendency to do silariang is heightened. In fact, in this situation when confronted by external factors and supported by internal factors, silariang is regarded as the only choice.

\section{Consequences of silariang}

Consequences of silariang found in this study is classified into internal and external consequences. Internally, silariang gives a psychological aftereffect to women who did it. In this study, it was found that there was regret after the decision of silariang was taken, in the form of remorse related to wedding ceremony, regret for making the parents sad, and regret because they feel they have destroyed their own future. The spiritual element is also found to emerge, silariang is perceived as destiny. Participants perceive silariang as part of the life journey that has been written for her. Participants also perceive themselves being happy, grateful and secure to have married the person they love.

Externally, silariang found to influence relationships with parents, extended families, husband's family, and social life. Participants of this study were found to undergo customary punishment in the form of prohibition to meet family. Some of these customary penalties are found to be strictly applied, where participants are prohibited to communicate with their family, whilst some of them can still communicate with some family members. Meanwhile, in relation to husband's family, it is found that as a new member who enter the family from silariang, instead of formal and more acceptable form of wedding, surprisingly, the women is well received in their husband's family and extended family. 
Interestingly, social environment, such as neighbor and friends are found not to be affected by participant's decision to do silariang. This study found that relationships of the three participants with their social environment are relatively good. A woman who do silariang is found to still get emotional support from their friend. Neighbors and communities of the residence were also found to not impose sanctions on customary violations committed by participants.

\section{Stages of decision to do silariang}

The decision to do silariang was begin when main factor presence and combined with reinforcing factor which occur in stage of recognition decision problem. Then, the main factor and reinforcing factor step in to differentiation stage which consists of screening, editing, and selection of decisions. The final product of this stage is the strongest alternative decision which in this context is silariang. In this study, participants were found not to think long and hard for other alternatives before deciding to do silariang. In participants perception, the choice are to whether to do or to not do silariang. Participants do understand that silariang is violating the customary law and might result in negative consequences, however, in the eye of participants, silariang is the only way to get marry and thus was chosen.

After decision to do silariang is taken, participants experience various feelings and thoughts. Psychologically, silariang result in regret and sadness, as well as happiness because they marry the person they love. In stage of consolidation, experience of happiness minimizes feeling of regret.

After silariang, participants were penalize by customary law. They are prohibited to meet their family. In the end, women who do silariang, try to fix their relationship with their family, by the process called abbaji'.

\section{DISCUSSION}

The purpose of this study is to describe the process of decision making in Makasarese women who do silariang. In particular, this study aims to get a better understanding on influencing factors, consequences and stages of decision making process in women who do silariang. The result of this study indicates that decision to do silariang was started from dating with a man they love. This relationship result in emotional dependency in participants. In the process, dating continues to pre-marital sex behavior, resulting in an out-ofwedlock pregnancy in Makassarese women. This situation is found to be the main factor to do silariang. In this study, out of wedlock pregnancy were found in women aged 19 and 18, which means that they are in period of adolescence. Santrock [7] argues that the period of adolescent development lies in the age range 18 to 22 years. The decision to do silariang in women in this research is supported by the men who also are adolescent.

According to Hurlock adolescent experience development of heterosexuality [8]. As their sexuality maturity occurs, adolescent develop different attitude toward opposite sex. They tend to have desire to opposite sex and prefer activity where they can meet their opposite sex. In community, this behavior is also known as dating.

In adolescence, since they are sexually matured, it is very important to be cautious in relations with the opposite sex. Many women start to become sexually active in their adolescence. As a consequence of this active sexual behavior, many women are encountered with sexual activity related problem, including pout of wedlock pregnancy. [7]. In this study, a wedlock pregnancy become one of the main influencing factor to do silariang. This findings add the prior understanding about what cause silariang, which are against matchmaking, economic factors, applications rejected because of differences in social status, and bad male behavior.

An out of wedlock pregnancy as a main factor to do silariang indicates that there is a shift in cultural value of siri', especially regarding opposite sex relationship. In research conducted by Sallatang, it was found that at that time, meeting, and even communication between man and women was restricted [9]. This was done to protect women honor and dignity. In fact, there was a social demand to close access that allows teenage girls and men together in one place. This is done as a strict supervision and restriction on the relationship between women and men.

Reflecting in implementation of siri' in the past, sex outside marriage was strictly prohibited especially in women as symbol of siri' . In fact, traditional Makassarese believe that protecting and raising a girl is more complicated than raising a hundred of buffalo. Siri's tradition of making women a symbol of honor includes the sanctity and virginity of a woman [1]. Based on that, it can inferred that sex outside marriage is unacceptable behavior. Sex is sacral and should be done only between husband and wife. Before having sex, a man and women should get marry first. However, since the provision rules to get marry and to hold a wedding festive is so hard, couples decide to do silariang. In other words, when there are obstacles that make the marriage cannot be done as ruled by customary law, silariang was taken as a way to keep themselves from premarital sex.

However, the results of this study indicate a shift from cultural values of siri'. In the past, silariang was done to preserve honor and dignity of the women to not involve in premarital sex as well as an attempt to stay together with the one they love. Contrary to the results of this study, of which silariang was taken as a solution deviant behavior in this context, that is premarital sex.

Olson \& DeFrain suggest that premarital pregnancy as a negative reason for marriage [10]. Individuals decide to get marry because of the urgency of the situation. In this study, premarital pregnancy Is found to be the main factor as well as reinforcing factor to do silariang.

This study also found that silariang was as way to get married in a cheaper way. Based on customary provision, a man should provide certain amount of money called uang panai'. This money is given to the bride to hold a wedding. Traditionally, the number of money represent the social status also the honor and dignity of the women. Makassarese encourage the tradition of uang panai' in order to glorify the 
women [1]. However, if the women has done silariang in the past, the women are deemed to have abandoned their dignity and honor, thus the amount of uang panai' will be lower, or less compare to women who maintain her honor and dignity. In fact, after silariang was done in the past, the husband is allow to ask for waiver of uang panai'.

This situation indicates that silariang may serve as a new way to be married with their love one. In the past, perpetrators of silariang were ostracized from family. They were prohibited to contact their family. However, with the opportunity to fix the relation with their family, or abbaji', consequences of choosing silariang is less severe compare to the opportunity to stay together with their love one. In other words, silariang became a "shortcut" especially for individuals who cannot afford the amount of uang panai'. Dignity and honor of women first demolished by doing silariang, so women and his partner can still live together with less severe consequences.

Another reason to do silariang is conflict with parents, thus the couples decide to marry by elope. Olson \& DeFrain [10] also argued that conflict with parents was one of the negative reasons for marriage. Marriage is used as a repressive form of conflict with parents or disturbed family functions. Individuals who have experienced long-term conflicts with parents, such as physical and emotional abuse, will feel they have a reason to escape from the family, then get married. In this study, the decision to elope is found in participants who have a bad relationship with parents, especially her father, of whom known to treat participants with physical violence. The decision to do silariang is found gives happiness to participants as she feels free from the pressure that comes from physical violence committed by his father. In addition, it was found that women who elope was well received by the husband' $\mathrm{s}$ family. This acceptance is seen as a form of husband' $\mathrm{s}$ family responsibility, because woman's decision to do silariang is inseparable from the presence and agreement with the man who is essentially a part of family members.

According to perspective of decision making, decision making is influenced by aspects of circumstances, preferences, actions, emotions, and beliefs [4]. In this study, in aspects of circumstances decision to do silariang is influenced by presence of external situation and influence of others. External situations found consists of conflicts between father and spouse, inability to meet the amount of uang panai', and condition of premarital pregnancy. Decision to do silariang mostly influenced by both part, women and men, since it was based on mutual agreement of both parties. After faced with an external situation that is considered to have no solution other than silariang. Furthermore, in aspect of preferences, there is a tendency cover the shame due to out of wedlock pregnancy, so both men and women decide to get married, even by silariang. In aspect of action, the decision was made, participants were found to interact with their social environment although there were significant effect on decision to do silariang . In emotion aspect, it is found that the starting point of decision to do silariang is the feeling which is perceived as love. This perception of love then elicits other feelings including fears of abandonment, physical inadequacy, and fears of deviant behavior. Saragih \& Irmawati [11] suggest that the feelings of love affect physical reaction and bring up unpleasant feelings, including sadness and anger, and thus trigger the decision to do silariang. In beliefs aspect, the feeling of love even influence belief of individual that silariang is the only choice they have, although it is contradicted with their cognition which know that silariang is violating the customary law of Makassar tribe.

Decision to elope is violating the customary law and thus result in consequences, both internal and external. Internally, silariang result in psychological condition. This result is in accordance with research by Utami which proposes that marriage decision was taken because of the premarital pregnancy, love and desire to live together with the love one, also intention to give a father to the unborn child [12]. Negative consequences for this action includes sadness, confusion, discomfort, even regret. Participants experience sadness because she has left her family, some even experience regret because not being able to continue their education.

In addition to the internal consequences, silariang also result in external consequence. Because it is violating customary law, perpetrators of silariang is banned to meet their family, including parents. In fact, for extreme cases, they are even considered no longer part of a family member. In this study, varied customary law sanctions are implemented. There are participants who are hardly sanctioned, while in others, the sanction are more relaxed. In strictly sanctioned, women as perpetrators of silariang are found really unable to meet their family, not even able to communicate until the perpetrators are able to perform abbaji' process. This findings is similar with research by Afandy which proposes that customary law sanction is still implemented to perpetrators of silariang [13]. Furthermore, customary sanction were applied to restore honor of the family since family consider silariang as embarrassment. (appakasiri'). Prohibition to meet family is considered less severe compared to termination of family relations [14]. In contrast, there are also more relaxed sanction applied of which perpetrators of silariang are still well received by both part of family members, except father. This differed implementation of customary sanction result in different deterrent effect on the perpetrators.

Ranyard et al. argues that the individual decision-making process begins with the stage of recognition decision problem which consists of identifying alternative decisions and goals to be achieved, and processing information based on perceptions and cognitions related to decisions to be made [4]. In this study, before deciding to get married, individuals actually have other alternative options, but are inadequate to do so tend to be ignored. In an individual with premarital pregnancy situation, her alternative was have an abortion, whereas in the other individual the alternative was to wait until the money for uang panai' is collected.

The next stage is differentiation. In this study, the process of screening, editing, and selection of alternative choices result in the decision goal to get married. However, alternative choice available only to get married by elope, or silariang. Participants are aware that their decision to do silariang might result in negative consequences after silariang of which they should live with. However, in the perception of the participants silariang are more visible choice, or considered has better consequences, and thus other options are abandoned. 
The next step is decision consolidation. This stage is done to minimize cognitive regret and dissonance. As previously explained, participants are aware of their mistake. In fact, decision to do silariang turned out to give negative effect such as sadness and regret. This sadness and regret is then managed and overcome by the individual's spiritual element, a belief that what has happened is a destiny. Therefore, in the decisionconsolidation stage, individuals are found to be able to minimize the regret that arises from the decision to do silariang.

This study found that silariang is not merely caused by love, rather is dominantly influenced by external factors such as conflicts with fathers, out of wedlock pregnancy, and inability to meet the amount of uang panai'. This findings of suggest that love is not the only reason of why people decide to elope, which might result in negative perception toward love. It should be noted that the most dominant factors influencing to do silariang is external factor, as such, there is possible prevention through a rational approach that can be done to prevent silariang. This findings also serve as source of information for further investigation to examine silariang by employing psychology variables which will provide a better understanding regarding this behavior. Further work is also required to get a better understanding regarding other behavior that deviates from customary law, so prevention can be planned. This will be a meaningful step to re-implement the customary law in social life, and bring back people life into a cultured society.

\section{REFERENCES}

[1] Israpil. "Silariang dalam Perspektif Budaya Siri' Pada Suku Makassar". Makassar: Jurnal Pustaka, pp 53-67, 2015.

[2] M. Brownlee. "Pengambilan Keputusan Etis dan Faktor-Faktor di Dalamnya". Jakarta: PT BPK Gunung Mulia, 2006.

[3] Y. Wang and G. Ruhe. "The Cognitive Process of Decision Making". International Journal of Cognitive Informatics and Natural Intelligence, vol 1(2), pp. 73-85, 2007.

[4] R. Ranyard, W. Crozier, and O. Svenson. "Decision Making: Cognitive Models and Explanations". New York: Library of Congress Catalogue in Publication Data, 2002.

[5] J. Creswell, J. "Penelitian Kualitatif \& Desain Riset: Memilih di antara Lima Pendekatan". Yogyakarta: Pustaka Pelajar, 2015.

[6] J. Creswell. "Research Design: Pendekatan Kualitatif, Kuantitatif, dan Metode Campuran”. Yogyakarta: Pustaka Pelajar, 2014.

[7] J.W. Santrock. "Life Span Development". Jakarta: Erlangga, 2007.

[8] Hurlock., Remaja. Jakarta: Erlangga, 1980.

[9] Marzuki, L., Siri': Bagian Kesadaran Hukum Rakyat Bugis-Makassar (Sebuah Telaah Filsafat Hukum). Ujung Pandang: Hasanuddin University Press, 1995.

[10] D. Olson and J.DeFrain. "Marriage and Families: Intimacy, Diversity, and Strengtsh". United States: McGraw-Hill, 2000.

[11] Saragih, J., \& Irmawati., Fenomena Jatuh Cinta Pada Mahasiswa. Psikologia, vol 1(1), pp 48-55, 2005.

[12] F. Utami. "Penyesuaian Diri Remaja Putri Yang Menikah di Usia Muda" Bachelor Thesis. Surakarta: Universitas Muhammadiyah Surakarta, 2009.

[13] Afandy, M., Analisis Hukum Terhadap Eksistensi Sanksi Adat A'Massa Pada Delik Silariang di Kabupaten Jeneponto. Skripsi, Makassar: Universitas Hasanuddin, 2016.

[14] I. Yani. "Penerapan Sanksi dalam Delik Adat Silariang di Masyarakat Hukum Adat Kajang Kabupaten Bulukumba (Studi Kasus Hukum Adat Kajang)”. Bachelor Thesis, Makassar: Universitas Hasanuddin, 2016. 